\title{
Heterotrophic denitrification vs. autotrophic anammox - quantifying collateral effects on the oceanic carbon cycle
}

\author{
W. Koeve and P. Kähler \\ IFM-GEOMAR, Leibniz-Institut für Meereskunde, Düsternbrooker Weg 20, 24105 Kiel, Germany
}

Received: 8 February 2010 - Published in Biogeosciences Discuss.: 16 March 2010

Revised: 14 July 2010 - Accepted: 24 July 2010 - Published: 6 August 2010

\begin{abstract}
The conversion of fixed nitrogen to $\mathrm{N}_{2}$ in suboxic waters is estimated to contribute roughly a third to total oceanic losses of fixed nitrogen and is hence understood to be of major importance to global oceanic production and, therefore, to the role of the ocean as a sink of atmospheric $\mathrm{CO}_{2}$. At present heterotrophic denitrification and autotrophic anammox are considered the dominant sinks of fixed nitrogen. Recently, it has been suggested that the trophic nature of pelagic $\mathrm{N}_{2}$-production may have additional, "collateral" effects on the carbon cycle, where heterotrophic denitrification provides a shallow source of $\mathrm{CO}_{2}$ and autotrophic anammox a shallow sink. Here, we analyse the stoichiometries of nitrogen and associated carbon conversions in marine oxygen minimum zones (OMZ) focusing on heterotrophic denitrification, autotrophic anammox, and dissimilatory nitrate reduction to nitrite and ammonium in order to test this hypothesis quantitatively. For open ocean OMZs the combined effects of these processes turn out to be clearly heterotrophic, even with high shares of the autotrophic anammox reaction in total $\mathrm{N}_{2}$-production and including various combinations of dissimilatory processes which provide the substrates to anammox. In such systems, the degree of heterotrophy $\left(\Delta \mathrm{CO}_{2}: \Delta \mathrm{N}_{2}\right)$, varying between 1.7 and 6.5 , is a function of the efficiency of nitrogen conversion. On the contrary, in systems like the Black Sea, where suboxic Nconversions are supported by diffusive fluxes of $\mathrm{NH}_{4}^{+}$originating from neighbouring waters with sulphate reduction, much lower values of $\Delta \mathrm{CO}_{2}: \Delta \mathrm{N}_{2}$ can be found. However, accounting for concomitant diffusive fluxes of $\mathrm{CO}_{2}$, the ratio approaches higher values similar to those computed for open ocean OMZs. Based on this analysis, we question the significance of collateral effects concerning the trophic nature of suboxic $\mathrm{N}$-conversions on the marine carbon cycle.
\end{abstract}

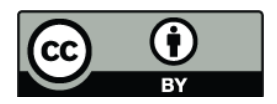

Correspondence to: W. Koeve (wkoeve@ifm-geomar.de)

\section{Introduction}

The importance and relative proportion of processes removing combined nitrogen from the marine environment is currently under discussion. There is evidence supporting the long standing view that heterotrophic denitrification dominates oceanic $\mathrm{N}$ loss, but also autotrophic anaerobic ammonium oxidation (anammox) has been reported to make up for large shares, or even the bulk, in certain waters (e.g. Thamdrup et al., 2006; Ward et al., 2009). Both processes convert fixed nitrogen into $\mathrm{N}_{2}$ (Ward et al., 2007; Devol, 2008) and reduce the oceanic nutrient inventory in this way. Temporal changes of the nitrogen removal flux in the past (on glacial/interglacial timescales), or from present to future, are thought to influence the level of oceanic production and associated $\mathrm{CO}_{2}$ fluxes (Altabet et al., 1995; Ganeshram et al., 1995; Codispoti, 1995) by tightening or relaxing Nlimitation of oceanic primary production and export. There are other aspects in which both processes differ (collateral effects, Voss and Montoya, 2009). One example is the formation of climate reactive gases, namely $\mathrm{N}_{2} \mathrm{O}$ (Jin and Gruber, 2003), which is an intermediate of denitrification (Yoshinari and Knowles, 1976) but not known as one of anammox. Here we focus on collateral effects of the trophic status of nitrogen loss processes on the carbon cycle, as recently proposed by Voss and Montoya (2009).

Their argument is the following. Denitrification is a heterotrophic process during which organic matter is consumed and $\mathrm{CO}_{2}$ is released to ambient waters. Pelagic denitrification thus effects a potential short-circuit in the biological pump by producing $\mathrm{CO}_{2}$ from organic matter which otherwise might descend deeper into the ocean to be stored there for longer. In contrast, anammox is an autotrophic process potentially increasing the efficiency of the biological pump by fixing additional carbon in intermediate waters and thus reducing net $\mathrm{CO}_{2}$ production in the water column. It appears to be of importance to the carbon budget whether it

Published by Copernicus Publications on behalf of the European Geosciences Union. 
Table 1. Stoichiometric equations for (1) dissimilatory nitrate reduction to nitrite (DNRN), (2) denitrification, (3) anammox, and (4) dissimilatory nitrate reduction to ammonium (DNRA) for bulk organic matter with an average composition of $\mathrm{C}_{\mathrm{a}} \mathrm{H}_{\mathrm{b}} \mathrm{O}_{\mathrm{c}} \mathrm{N}_{\mathrm{d}} \mathrm{P}_{\mathrm{e}} \mathrm{S}_{\mathrm{f}}$. For simplicity and following Paulmier et al. (2009) we give the stoichiometric equations in non-ionic forms. We assume reaction of $\mathrm{NH}_{3}$ and $\mathrm{CO}_{2}$ with water and subsequent dissociation as well as dissociation of $\mathrm{HNO}_{3}, \mathrm{HNO}_{2}, \mathrm{H}_{3} \mathrm{PO}_{4}$, and $\mathrm{H}_{2} \mathrm{SO}_{4}$ according to seawater $\mathrm{pH}$. For a more detailed discussion of the derivation of Eqs. (1), (2), and (3) see Paulmier et al. (2009).

\begin{tabular}{lll}
\hline \multicolumn{2}{c}{ Bulk reaction stoichiometry } & \\
\hline (1) $\quad$ & $\mathrm{C}_{\mathrm{a}} \mathrm{H}_{\mathrm{b}} \mathrm{O}_{\mathrm{c}} \mathrm{N}_{\mathrm{d}} \mathrm{P}_{\mathrm{e}} \mathrm{S}_{\mathrm{f}}+x \mathrm{HNO}_{3} \rightleftharpoons a \mathrm{CO}_{2}+d \mathrm{NH}_{3}+e \mathrm{H}_{3} \mathrm{PO}_{4}+f \mathrm{H}_{2} \mathrm{SO}_{4}+y \mathrm{HNO}_{2}+z \mathrm{H}_{2} \mathrm{O}$ & DNRN \\
& with $x=2 a+0.5 b-c-1.5 d+2.5 e+3 f, y=x, z=0.5 b-1.5 d-1.5 e-f$. & \\
(2) $\quad$ & $\mathrm{C}_{\mathrm{a}} \mathrm{H}_{\mathrm{b}} \mathrm{O}_{\mathrm{c}} \mathrm{N}_{\mathrm{d}} \mathrm{P}_{\mathrm{f}}+x \mathrm{HNO}_{2} \rightleftharpoons a \mathrm{CO}_{2}+d \mathrm{NH}_{3}+e \mathrm{H}_{3} \mathrm{PO}_{4}+f \mathrm{H}_{2} \mathrm{SO}_{4}+y \mathrm{~N}_{2}+z \mathrm{H}_{2} \mathrm{O}$ & denitrification \\
& with $x=4 / 3 a+1 / 3 b-2 / 3 c-d+5 / 3 e+2 f$, & \\
& $y=2 / 3 a+1 / 6 b-1 / 3 c-0.5 d+5 / 6 e+f$, & \\
& $z=2 / 3 a+2 / 3 b-1 / 3 c-2 d-2 / 3 e$. & \\
(3a) & $x \mathrm{NH}_{3}+x \mathrm{HNO}_{2} \rightleftharpoons x \mathrm{~N}_{2}+2 x \mathrm{H}_{2} \mathrm{O}$ & \\
(3b) & $y \mathrm{HNO}_{2}+z \mathrm{CO}_{2} \rightleftharpoons z \mathrm{CH}_{2} \mathrm{O}_{0.5} \mathrm{~N}_{0.15}+w \mathrm{H}_{2} \mathrm{O}$ & \\
(4) $\quad$ & $\mathrm{C}_{\mathrm{a}} \mathrm{H}_{\mathrm{b}} \mathrm{O}_{\mathrm{c}} \mathrm{N}_{\mathrm{d}} \mathrm{P}_{\mathrm{f}}+x \mathrm{HNO}_{3} \rightleftharpoons a \mathrm{CO}_{2}+y \mathrm{NH}_{3}+e \mathrm{H}_{3} \mathrm{PO}_{4}+f \mathrm{H}_{2} \mathrm{SO}_{4}+z \mathrm{H}_{2} \mathrm{O}$ & \\
& with $x=0.5 a+0.125 b-0.25 c-0.375 d+0.625 e+0.75 f$, & \\
& $y=0.5 a+0.125 b-0.25 c+0.625 d+0.625 e+0.75 f=x+d$, & \\
& $z=-0.5 a+0.375 b+0.25 c-1.125 d-2.125 e-1.75 f$. & \\
\hline
\end{tabular}

${ }^{a}$ The energy gain from the anammox reaction (3a) is used to drive the fixation of $\mathrm{CO}_{2}$ into organic matter (biomass of anammox bacteria). Here we follow the suggestion of Strous et al. (1998) and Kuenen (2008) that nitrite is used in this reaction as the electron donor of $\mathrm{CO}_{2}$ fixation (Eq. $3 \mathrm{~b}$ ). Since the combined system of equations (3a, 3b) is underdetermined we are unable to provide a generic solution for $x, y, z$, and $w$. In our computations we use instead empirical values taken from the experimental work of Strous et al. (1998), i.e. $z / x=0.066 \mathrm{~mol} \mathrm{CO}_{2}: \mathrm{mol} \mathrm{NH}_{4}^{+}$and $z / y=0.066 / 0.26 \mathrm{~mol} \mathrm{CO}_{2}: \mathrm{mol} \mathrm{NO}_{2}^{-}$. In the $\Delta \mathrm{CO}_{2}: \Delta \mathrm{N}_{2}$ ratios of Figs. 2a, 4b, and 6, these effects of autotrophic $\mathrm{CO}_{2}$-fixation are included.

is a heterotrophic process or an autotrophic one which dominates nitrogen loss processes in the ocean's water column. In view of projected increases in the extent of oxygen minimum zones (Matear and Hirst, 2003; Oschlies et al., 2008; Hofmann and Schellnhuber, 2009), heterotrophy or autotrophy in relation to nitrogen losses taking place there would be of increasing importance, potentially providing a positive or negative feedback on the carbon cycle, respectively. In this short note we analyse the stoichiometries of suboxic nitrogen conversions and their effect on the carbon balance.

\section{Heterotrophy vs. autotrophy of $\mathbf{N}_{2}$ production in OMZs}

\subsection{Background and definitions}

Nitrogen in the ocean occurs in seven oxidation states and there are transformations between all, oxidations and reductions. Nitrogen serves both as a constituent of organic matter and nitrogen compounds are used as oxidants and reductants in dissimilatory reactions. Historically, a number of terms, and varieties of definitions of some, have been in use for many of these reactions. We will in the following use only four reactions, all relevant to nitrogen loss in suboxic environments: (1) dissimilatory nitrate reduction to nitrite (DNRN); (2) denitrification, the production of $\mathrm{N}_{2}$ from nitrite (denitrification sensu strictu; Zumft, 1997), this is a heterotrophic process consuming organic carbon; (3) anammox, the combination of nitrite and ammonia to produce $\mathrm{N}_{2}$, which is an autotrophic process consuming $\mathrm{CO}_{2}$; (4) dissimilatory nitrate reduction to ammonia (DNRA). Both DNRN and DNRA are heterotrophic. Formulas describing the bulk stoichiometries of these processes are given in Table 1. We use only these four definitions of suboxic nitrogen transformations to develop our points. There are numerous variations to these (incomplete reactions, shortcuts, combinations, byreactions) which can be of interest in special environments. We confine the treatment to oxygen minimum zones (OMZ) which are the only pelagic realms in which nitrogen loss occurs (at $\left[\mathrm{O}_{2}\right]<5 \mathrm{mmol} \mathrm{m}^{-3}$; Devol, 2008). In the cores of OMZs, $\mathrm{N}$ transformations are based on the $\mathrm{N}$ inventory present plus anything which reaches them by sedimentation. It is these that we start with (Sects. 2.1 and 2.2). Later we shall consider the allochthonous supply of additional substrates by diffusion from the fringes of the OMZ, and other special situations encountered in the sea (Sects. 2.3 and 3).

The largest oxygen minimum zones (OMZ) meeting these low oxygen conditions are the intermediate to deep waters of the Arabian Sea and the Eastern Tropical South and North Pacific. Additional sites of suboxic nitrogen removal are enclosed seas like the Black Sea, the Baltic Sea and some fjords. While until recently all suboxic $\mathrm{N}_{2}$-production in the ocean has been ascribed to denitrification, it is now known that a number of biotic and abiotic nitrogen transformations contribute to nitrogen loss (Hulth et al., 2005). At present denitrification and anammox are considered the most important ones for $\mathrm{N}_{2}$ production (e.g. Thamdrup et al., 2006; Ward et al., 2009). 
Already during early work on denitrification, it had been observed that this process cannot account for all observed nitrogen loss. Ammonia liberated from organic matter during its heterotrophic consumption by denitrification and DNRN should accumulate in an oxygen-free environment, but it does not (Thomas, 1966; Cline and Richards, 1972; Codipoti and Christensen, 1985). Therefore a reaction involving the combination of $\mathrm{NO}_{3}^{-}$and $\mathrm{NH}_{4}^{+}$to produce $\mathrm{N}_{2}$ has been invoked (Richards, 1965; Sen Gupta and Koroloff, 1973; Stumm and Morgan, 1996) and deduced from evolutionary and thermodynamical knowledge (Broda, 1977). Finally, a similar reaction has been observed in nature (Mulder et al., 1995; Thamdrup and Dalsgaard, 2002; Kuypers et al., 2003), the combination of $\mathrm{NO}_{2}^{-}$and $\mathrm{NH}_{4}^{+}$to form $\mathrm{N}_{2}$, which was called anaerobic ammonium oxidation (anammox).

During anammox $\mathrm{NH}_{4}^{+}$and $\mathrm{NO}_{2}^{-}$react in an approximately equimolar ratio (Table 1). Since oceanic OMZs are extensive lenses of oxygen free water surrounded by oxygen rich waters above, below and at least towards the open sea, and since $\mathrm{NH}_{4}^{+}$and $\mathrm{NO}_{2}^{-}$are usually scarce in these surrounding oxic waters (Zafiriou et al., 1992; Brzezinski, 1988), the major sources of the reactants of anammox must be autochthonous, i.e. $\mathrm{NH}_{4}^{+}$and $\mathrm{NO}_{2}^{-}$must be produced in the suboxic water body itself. Anammox therefore depends on nutrient regeneration for the supply of both its substrates $\left(\mathrm{NH}_{4}^{+}\right.$and $\mathrm{NO}_{2}^{-}$) (Ward et al., 2009). In principle, $\mathrm{NO}_{2}^{-}$can be supplied by DNRN (Table 1) and $\mathrm{NH}_{4}^{+}$may be liberated from organic matter broken down during DNRN or denitrification. The low production ratios of $\mathrm{NH}_{4}^{+}: \mathrm{NO}_{2}^{-}$of these reactions (compare Fig. 1b), however, allow only for a limited quantitative importance of anammox for $\mathrm{N}_{2}$ production (see Sect. 2.2 for details). An alternative and additional autochthonous source of $\mathrm{NH}_{4}^{+}$may be dissimilatory nitrate reduction to ammonium (DNRA; Kartal et al., 2007; Lam et al., 2009) which is associated with heterotrophy as well.

In this paper, we will refer to the conversion of fixed nitrogen (i.e. the sum of $\mathrm{NO}_{3}^{-}, \mathrm{NO}_{2}^{-}, \mathrm{NH}_{4}^{+}$, and organic nitrogen) to nitrogen gas $\left(\mathrm{N}_{2}\right)$ in suboxic waters as "suboxic $\mathrm{N}_{2}$-production", irrespective of the pathways or agents (organisms) involved. Different stoichiometries of suboxic nitrogen conversions have been discussed in the literature, differing by the composition of the organic matter utilized and the fate of remineralised nitrogen (e.g. Richards, 1965; Canfield, 2006; Paulmier et al., 2009). In the following section we will present the bulk stoichiometries of two possible systems, one consisting of combinations of DNRN, denitrification and anammox (i.e. a system where heterotrophic denitrification necessarily dominates $\mathrm{N}_{2}$ production) and an alternative system where DNRN, DNRA and anammox co-exist (i.e. a system where autotrophic anammox is the exclusive process forming gaseous nitrogen). We will also briefly discuss to what extent and under which specific conditions allochthonous sources of substrates can be relevant and evaluate their maximum effect on the trophic state of the suboxic
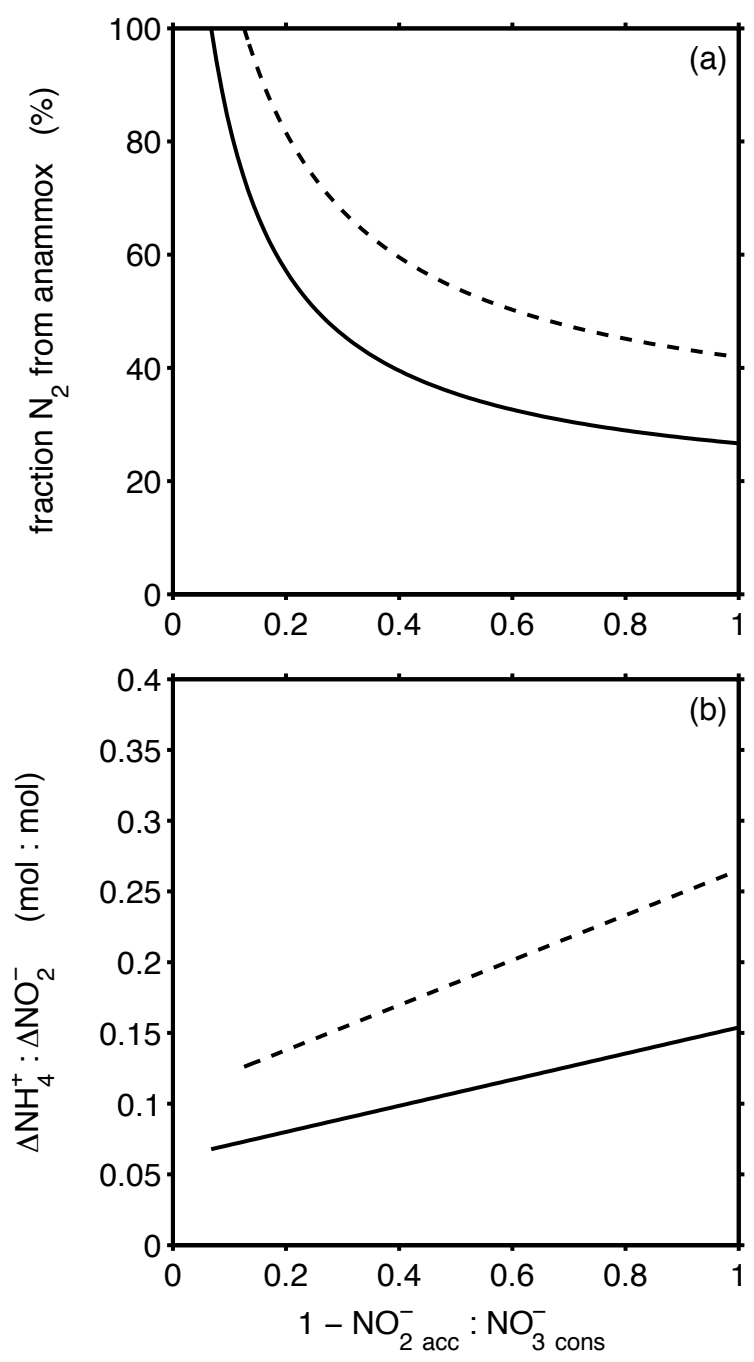

Fig. 1. Scenario I, assuming that suboxic N-conversions are due to a combination of DNRN, denitrification and anammox such that no $\mathrm{NH}_{4}^{+}$but variable fractions of $\mathrm{NO}_{2}^{-}$accumulate. On the x-axes we plot the property " $1-\mathrm{NO}_{2}^{-}$accumulated $: \mathrm{NO}_{3}^{-}$-consumed". We interpret this property as the efficiency of the overall $\mathrm{N}$-conversion process where the value of one represents the condition of a fully efficient conversion of $\mathrm{NO}_{3}^{-}$to $\mathrm{N}_{2}$ (i.e. all $\mathrm{NO}_{2}^{-}$is used up). Solid lines are for a mean composition of respired organic matter of $\mathrm{C}_{106} \mathrm{H}_{175} \mathrm{O}_{42} \mathrm{~N}_{16} \mathrm{P}$ (Anderson, 1995), dashed lines for respiration of pure proteins $\left(\mathrm{C}_{3.83} \mathrm{H}_{6.05} \mathrm{O}_{1.25} \mathrm{~N}\right.$, Laws, 1991; Anderson, 1995). (a) Fraction (in percent) of total $\mathrm{N}_{2}$-production which is due to anammox. In the combined reactions of scenario I the remainder to 100 percent is due to denitrification. (b) Ratio of production rates of $\mathrm{NH}_{4}^{+}$and $\mathrm{NO}_{2}^{-}$(mol:mol) during the coupled reactions of DNRN (providing $\mathrm{NH}_{4}^{+}$and $\mathrm{NO}_{2}^{-}$) and denitrification (providing $\mathrm{NH}_{4}^{+}$only) for the given boundary conditions (no $\mathrm{NH}_{4}^{+}$accumulation) and the respective efficiencies of the overall $\mathrm{N}$-conversion process (x-axes). Note that this ratio is always well below one, the stoichiometric ratio of $\mathrm{NH}_{4}^{+}$and $\mathrm{NO}_{2}^{-}$in anammox, indicating $\mathrm{NH}_{4}^{+}$ limitation of anammox. 
layer. Our general subject will be to quantify the net ratio of $\mathrm{CO}_{2}$ produced to molecular nitrogen formed $\left(\Delta \mathrm{CO}_{2}: \Delta \mathrm{N}_{2}\right)$ given various combinations of the processes involved in suboxic N-conversions.

\subsection{Stoichiometric constraints}

First, let us consider the simple case that organic matter of standard oceanic composition $\left(\mathrm{C}_{106} \mathrm{H}_{175} \mathrm{O}_{42} \mathrm{~N}_{16} \mathrm{P}\right.$; Anderson, 1995) is completely oxidized with nitrate to form $\mathrm{CO}_{2}$, $\mathrm{N}_{2}$ and water according to Reaction (R1) (Canfield, 2006).

$$
\begin{aligned}
\mathrm{C}_{106} \mathrm{H}_{175} \mathrm{O}_{42} \mathrm{~N}_{16} \mathrm{P}+104 \mathrm{NO}_{3}^{-} \rightleftharpoons & 102 \mathrm{HCO}_{3}^{-}+4 \mathrm{CO}_{2}+60 \mathrm{~N}_{2} \\
& +\mathrm{HPO}_{4}^{2-}+36 \mathrm{H}_{2} \mathrm{O} \quad(\mathrm{R} 1)
\end{aligned}
$$

Complete oxidation here refers to the boundary condition that neither $\mathrm{NH}_{4}^{+}$nor $\mathrm{NO}_{2}^{-}$accumulate. This yields a ratio of organic carbon oxidized to nitrate consumed of close to $1\left(106 \mathrm{C}: 104 \mathrm{NO}_{3}^{-}\right)$and a gross ratio of $\mathrm{CO}_{2}$ produced to molecular nitrogen formed $\left(\Delta \mathrm{CO}_{2}: \Delta \mathrm{N}_{2}\right)$ of $+1.77(106 \mathrm{C}: 60$ $\mathrm{N}_{2}$ ). In suboxic waters no $\mathrm{NH}_{4}^{+}$accumulates (Richards, 1965) and here we assume that the oxidation of $\mathrm{NH}_{4}^{+}$is due to anammox. In this reaction $1 \mathrm{~mol}$ of $\mathrm{NH}_{4}^{+}$combines with $1 \mathrm{~mol}$ of $\mathrm{NO}_{2}^{-}$to form $1 \mathrm{~mol}$ of $\mathrm{N}_{2}$ and water (Eq. 3a in Table 1). Each mol of $\mathrm{NH}_{4}^{+}$consumed supports the autotrophic fixation of about $0.07 \mathrm{~mol}$ of $\mathrm{CO}_{2}$ (Strous et al., 1998; Tijhuis et al., 1993) yielding a molar $\Delta \mathrm{CO}_{2}: \Delta \mathrm{N}_{2}$ ratio of anammox of 0.07 . The electron donor required for the reduction of $\mathrm{CO}_{2}$ is not well known. In aerobic ammonium oxidation, $\mathrm{NH}_{4}^{+}$is the only reductant. In anammox, $\mathrm{NO}_{2}^{-}$has been proposed as the electron donor resulting in $\mathrm{NO}_{3}^{-}$as a product of $\mathrm{CO}_{2}$ fixation (van de Graaf et al., 1996; Strous et al., 1998; Eq. 3b in Table 1). During experiments in a sequencing batch reactor of these authors the ratio $\mathrm{NO}_{2}^{-}$consumed : $\mathrm{NH}_{4}^{+}$consumed differed significantly from the 1:1 ratio, which is usually assumed for marine anaerobic ammonium oxidation (e.g. Kuypers et al., 2003). About $20 \%$ of the nitrite was converted to nitrate and the $\Delta \mathrm{NO}_{2}^{-}: \Delta \mathrm{NH}_{4}^{+}$ratio of the combined reaction $(3 \mathrm{a}, 3 \mathrm{~b})$ was about 1.3:1. Under marine conditions, with substrate concentrations several orders of magnitude smaller than in the batch reactor experiments, a smaller $\Delta \mathrm{CO}_{2}: \Delta \mathrm{NH}_{4}^{+}$is expected because of the energy requirements for maintainance. This results in a lower $\Delta \mathrm{NO}_{2}^{-}: \Delta \mathrm{NH}_{4}^{+}$ratio of the combined reaction $(3 \mathrm{a}+3 \mathrm{~b})$. Even when assuming the published $\Delta \mathrm{NO}_{2}^{-}: \Delta \mathrm{NH}_{4}^{+}$ ratio from batch reactor experiments to be valid for marine anammox, the effect on the nitrogen budget of the $\mathrm{N}$ conversions is small. Consider the oxidation of a one mole P-equivalent of organic matter according to Reaction (R1) by DNRN+denitrification+anammox which consumes $104 \mathrm{~mol}$ of nitrate and implies the oxidation of $16 \mathrm{~mol}^{\circ} \mathrm{NH}_{4}^{+}$with 16 mol $\mathrm{NO}_{2}^{-}$due to anammox. The associated $\mathrm{CO}_{2}$ fixation should consume another $4 \mathrm{~mol}$ of nitrite and yield $4 \mathrm{~mol}$ nitrate, thus replenishing only about $4 \%$ of the nitrate consumed during DNRN+denitrification.
Using generic stoichiometric equations to describe the possible reactions which contribute to suboxic $\mathrm{N}_{2}$ production (Table 1) we can quantify the proportions in which the individual reactions involved (DNRN, denitrification, anammox) are required for a variety of bulk organic matter compositions (Table 2) and for a range of boundary conditions (fraction of accumulating intermediate $\mathrm{NO}_{2}^{-}$). For the mean organic matter composition given above, the condition of complete conversion of fixed nitrogen to $\mathrm{N}_{2}$, is met if $1 \mathrm{~mol} \mathrm{P}$-equivalent of organic matter is remineralised through DNRN, $1.27 \mathrm{~mol} \mathrm{P}$ equivalents of organic matter through denitrification and if the $2.27 \cdot 16 \mathrm{~mol} \mathrm{NH}_{4}^{+}$produced in these heterotrophic reactions are oxidized with $\mathrm{NO}_{2}^{-}$to form $\mathrm{N}_{2}$ via anammox. In this scenario about $73 \%$ of the $\mathrm{N}_{2}$ produced is by denitrification and $27 \%$ by anammox (Table 2). The respective autotrophic $\mathrm{CO}_{2}$ fixation is 2.54 $(0.07 \cdot 2.27 \cdot 16) \mathrm{mol}$ and the bulk $\Delta \mathrm{CO}_{2}: \Delta \mathrm{N}_{2}$ ratio for the combined heterotrophic and autotrophic processes changes to +1.75 . This is, for all practical purposes, indistinguishable from the gross ratio $(+1.77)$ which does not account for the autotrophic carbon fixation. The net $\Delta \mathrm{CO}_{2}: \Delta \mathrm{N}_{2}$ ratio for the complete conversion of fixed nitrogen to $\mathrm{N}_{2}$ may vary between 1.58 and 1.90, depending on the composition of organic matter (Table 2).

Significantly higher contributions of anammox to $\mathrm{N}_{2}$ production of up to $100 \%$ have been suggested from tracer experiments (Kuypers et al., 2005; Thamdrup et al., 2006; Hamersley et al., 2007). With a combination of DNRN, denitrification and anammox (scenario I, Figs. 1-3) this can be achieved if nitrite accumulates (Fig. 1a). Nitrite accumulation is a characteristic of the upper margin of oxygen minimum zones (Cline and Richards, 1972; Sen Gupta and Naqvi, 1984; Codispoti and Christensen, 1985). The ratio of nitrite accumulating to nitrate consumed denotes the inefficiency of suboxic $\mathrm{N}_{2}$-production. We use the term "1 $-\mathrm{NO}_{2}^{-}$accumulated $: \mathrm{NO}_{3}^{-}$consumed", i.e. the efficiency of suboxic $\mathrm{N}_{2}$-production, as the independent variable (x-axes) in Figs. 1-5. Contrary to expectations, a higher contribution of anammox to total $\mathrm{N}_{2}$ production goes along with an increase (and not a decrease or even turn in sign) of the ratio of $\mathrm{CO}_{2}$ produced to $\mathrm{N}_{2}$ formed $\left(\Delta \mathrm{CO}_{2}: \Delta \mathrm{N}_{2}\right.$, Fig. 2a). In the most extreme case (no denitrification, $100 \%$ anammox; high $\mathrm{NO}_{2}^{-}$accumulation) the ratio is about +6.5 , i.e. almost four times as high as for 100 percent efficient $\mathrm{N}_{2}$-production (Fig. 2a). This effect is due to the increased contribution of organic nitrogen to produced $\mathrm{N}_{2}$ (Fig. $2 \mathrm{~b}$ ). The higher the contribution from anammox the more inefficient the suboxic $\mathrm{N}$-removal becomes.

Direct and indirect effects of autotrophic $\mathrm{CO}_{2}$-fixation have a small impact on the integrated $\Delta \mathrm{CO}_{2}: \Delta \mathrm{N}_{2}-$ ratio (Fig. 3). The direct effect (from $\mathrm{CO}_{2}$-uptake) is largest where the contribution of anmmox is highest. The indirect effect (i.e. the effect of $\mathrm{NO}_{3}^{-}$-production on the x-value) is largest at moderatly low x-axes values (Fig. 3a). Taken 
Table 2. Bulk ratios for complete conversion of fixed nitrogen to $\mathrm{N}_{2}$ (i.e. no accumulation of $\mathrm{NO}_{2}^{-}$or $\mathrm{NH}_{4}^{+}$) for different compositions of organic matter. Bulk $\Delta \mathrm{CO}_{2}: \Delta \mathrm{N}_{2}$ ratios include the effect of autotrophic $\mathrm{CO}_{2}$ fixation (data for scenario I, with DNRN, denitrification and anammox, only).

\begin{tabular}{|c|c|c|c|c|c|c|}
\hline & $\begin{array}{l}\Delta \mathrm{CO}_{2}: \Delta \mathrm{N}_{2} \\
\text { mol:mol }\end{array}$ & $\begin{array}{l}\text { Den:DNRN } \\
\text { mol:mol }\end{array}$ & $\begin{array}{l}\mathrm{N}_{2} \text {-anammox:total } \\
\mathrm{N}_{2} \text {-production, } \%\end{array}$ & $\begin{array}{l}\mathrm{N}_{2} \text { from org } \mathrm{N} \\
\%\end{array}$ & $\begin{array}{l}\Delta \mathrm{PO}_{4}^{3-}: \Delta \mathrm{N}_{2} \\
\text { mol:mol }\end{array}$ & $\begin{array}{l}\Delta \mathrm{N}_{2}-\mathrm{N}: \Delta \mathrm{NO}_{3}^{-} \\
\text {mol:mol }\end{array}$ \\
\hline $\begin{array}{l}\mathrm{C}_{106} \mathrm{H}_{175} \mathrm{O}_{42} \mathrm{~N}_{16} \mathrm{P} \\
\text { Anderson }(1995)\end{array}$ & 1.75 & 1.27 & 26.6 & 19.2 & 0.017 & 1.15 \\
\hline $\begin{array}{l}\mathrm{C}_{3.83} \mathrm{H}_{6.05} \mathrm{O}_{1.25} \mathrm{~N} \\
\text { Laws }(1991)\end{array}$ & 1.58 & 1.10 & 41.9 & 28.8 & 0 & 1.27 \\
\hline $\begin{array}{l}\mathrm{C}_{106} \mathrm{H}_{263} \mathrm{O}_{110} \mathrm{~N}_{16} \mathrm{P} \\
\text { Redfield et al. (1963) }\end{array}$ & 1.9 & 1.25 & 29.0 & 20.7 & 0.018 & 1.17 \\
\hline
\end{tabular}

a Ratio of denitrification to DNRN, in mol:mol of organic matter oxidized, respectively.

together, the combined effect is within $\pm 1 \%$ of the uncorrected $\Delta \mathrm{CO}_{2}: \Delta \mathrm{N}_{2}$ (Fig. 3b).

Alternatively, OMZs may function as systems in which dissimilatory nitrate reduction to ammonium (DNRA) supplements the respiratory pathways of DNRN and denitrification in the production of ammonium to supply substrates to anammox (Lam et al., 2009; Eq. 4 in Table 1). In this case high shares of anammox in total $\mathrm{N}_{2}$-production may be achieved even with no or little nitrite accumulation, i.e. with highly efficient nitrogen removal. Here (scenario II, Fig. 4) we assume combinations of DNRA (major $\mathrm{NH}_{4}^{+}$source), DNRN (prime source of $\mathrm{NO}_{2}^{-}$and minor $\mathrm{NH}_{4}^{+}$source), and anammox as the only process producing $\mathrm{N}_{2}$. Combining DNRA and DNRN in variable ratios yields a range of efficiencies of $\mathrm{N}_{2}$-production (x-axes) accompanied by varying $\mathrm{NO}_{2}^{-}$-accumulation (again using the boundary condition that no $\mathrm{NH}_{4}^{+}$should accumulate).

Both DNRA and DNRN are heterotrophic. Figure 4a shows their relative contribution along the efficiency gradient expressed as the fraction of $\mathrm{NH}_{4}^{+}$provided via DNRA, to the total flux of $\mathrm{NH}_{4}^{+}$to anammox. High contributions of DNRA allow for highly efficient $\mathrm{N}$-conversion while low efficiencies are found where $\mathrm{NH}_{4}^{+}$provision from DNRA falls below 50\%. Although in this scenario 100 percent of $\mathrm{N}_{2}$ production is from the autotrophic anammox reaction for all possible efficiencies, the overall process (i.e. the combined net effects of DNRA, DNRN, and anammox) is clearly heterotrophic (Fig. 4b), with $\Delta \mathrm{CO}_{2}: \Delta \mathrm{N}_{2}$ ratios almost indistinguishable from those given in Fig. 2a where DNRN, denitrification, and anammox co-exist.

Differences occur related to the quality of organic matter consumed during the $\mathrm{N}$-conversions. Using protein instead of mean bulk organic matter, the $\Delta \mathrm{CO}_{2}: \Delta \mathrm{N}_{2}$ ratio is somewhat lower (Figs. 2a, 4b) and the yield of $\mathrm{N}_{2}-\mathrm{N}$ produced per nitrate molecule consumed is larger (Fig. 5b) with maximum values of 2 in the case of very inefficient $\mathrm{N}$-conversion. The major difference, however, is in the molar $\Delta \mathrm{PO}_{4}^{3-}: \Delta \mathrm{N}_{2}$ yield (Fig. 5a). For mean bulk organic matter of a composi- tion commonly used in global biogeochemical models (Paulmier et al., 2009), the $\Delta \mathrm{PO}_{4}^{3-}: \Delta \mathrm{N}_{2}$ yield increases from about $0.02 \mathrm{~mol} \mathrm{P}: \mathrm{mol}_{2}$ (efficient $\mathrm{N}$-conversion) to about 0.06 (highly inefficient $\mathrm{N}$-conversion). If, however, mainly proteins were preferentially respired in OMZs as indicated by recent particle-flux and decay studies (van Mooy et al., 2002), the $\Delta \mathrm{PO}_{4}^{3-}: \Delta \mathrm{N}_{2}$ yield should be much smaller and even approach zero (Fig. 5a).

Assuming that autochthonous substrates to the anammox reaction dominate in typical open ocean OMZs, we find that although anammox itself is autotrophic, the sum of processes providing substrates for anammox and/or denitrification in all possible combinations of DNRN, denitrification, DNRA and anammox is heterotrophic. The degree of this heterotrophy depends on the efficiency of $\mathrm{N}_{2}$-production. In a combination of DNRN, denitrification, and anammox it is actually positively correlated with the importance of anammox for $\mathrm{N}_{2}$ production (Fig. 6).

\subsection{Allochthonous substrate sources}

So far we addressed a typical open-ocean OMZ bounded by oxic waters where substrates to anammox are autochthonous, i.e. produced within the OMZ. This is in particular relevant for $\mathrm{NH}_{4}^{+}$, which appears to be limiting to anammox in a system characterized by DNRN, denitrification and anammox. Potential external sources of $\mathrm{NH}_{4}^{+}$are anoxic waters or sediments located below suboxic zones and the primary ammonia maximum at the base of the euphotic zone. In this section we discuss the potential effects of allochthonous substrate sources for $\Delta \mathrm{CO}_{2}: \Delta \mathrm{N}_{2}$ ratios.

In sediments or enclosed seas like the Black Sea, suboxic waters may sit on top of fully anoxic systems in which $\mathrm{NH}_{4}^{+}$has accumulated which has been produced from organic matter remineralised by sulphate reduction (Codispoti et al., 1991). Here, diffusive flux provides for additional $\mathrm{NH}_{4}^{+}$available to anammox in adjacent suboxic waters (Murray et al., 2005). Additionally, reactions of $\mathrm{HS}^{-}$, another product of sulphate reduction, diffusing upwards combining 

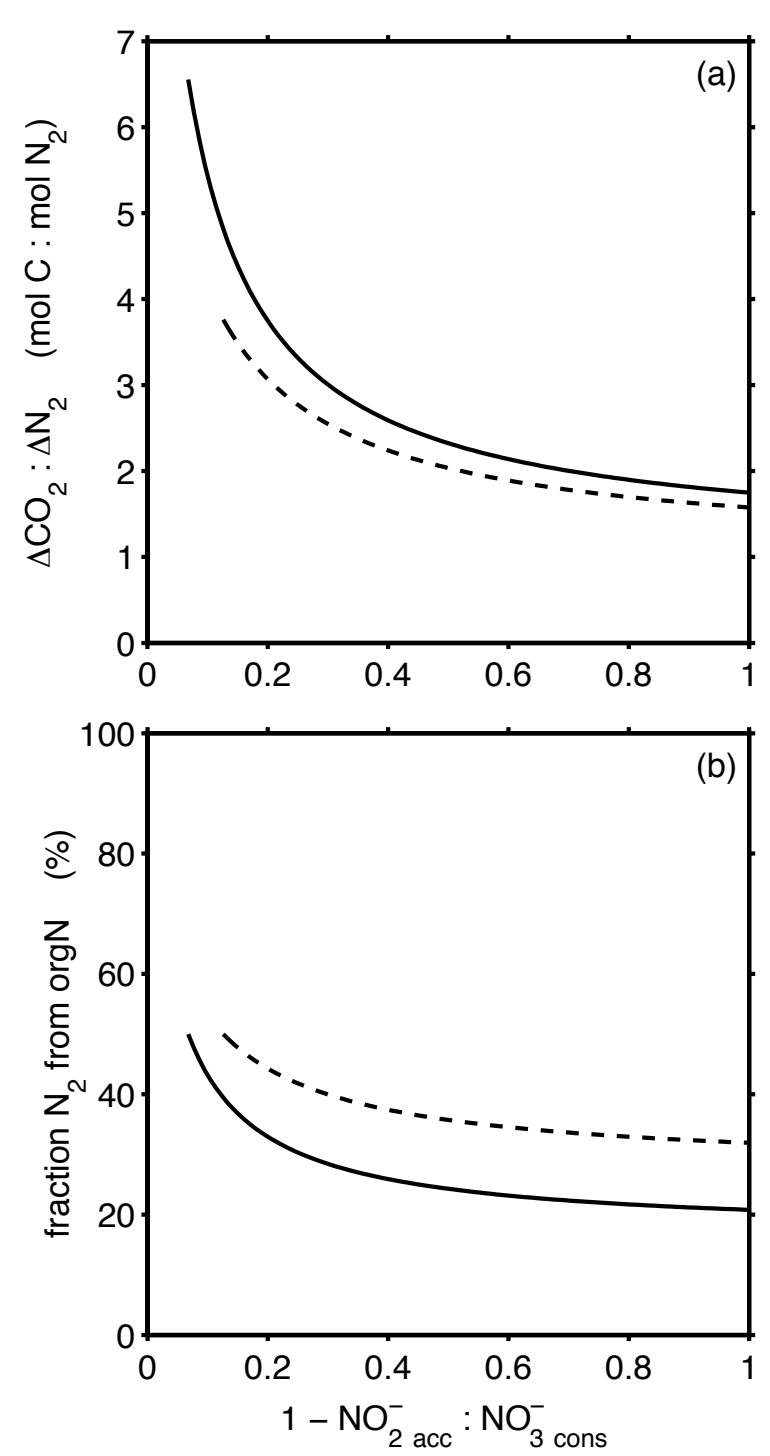

Fig. 2. Same N-conversion scenario as Fig. 1 (DNRN+denitrification+anammox; solid lines for OM composition of $\mathrm{C}_{106} \mathrm{H}_{175} \mathrm{O}_{42} \mathrm{~N}_{16} \mathrm{P}$; dashed lines for proteins). (a) The net ratio of $\mathrm{CO}_{2}$ to $\mathrm{N}_{2}$ release $\left(\Delta \mathrm{CO}_{2}: \Delta \mathrm{N}_{2}, \mathrm{~mol}\right.$ :mol) as a function of $\mathrm{N}$-conversion efficiency. The ratios include a correction for autotrophic $\mathrm{CO}_{2}$ fixation during anammox. (b) Percent fraction of $\mathrm{N}_{2}$-production supported by nitrogen from respired organic matter.

with nitrate diffusing downwards from overlying oxic waters may provide additional nitrite or ammonium (Konovalov et al., 2008) to support anammox and/or denitrification. In a system like the Black Sea such allochtonous sources of substrates may dominate (Fuchsman et al., 2008). Assuming DNRN as the sole $\mathrm{NO}_{2}^{-}$source and diffusive $\mathrm{NH}_{4}^{+}$fluxes as the major $\mathrm{NH}_{4}^{+}$supply of anammox in the suboxic layers of the Black Sea, the net $\Delta \mathrm{CO}_{2}: \Delta \mathrm{N}_{2}$ ratio may be as low as 0.38 inside the suboxic layer. This is still heterotrophic, but to a much lesser degree than under the conditions discussed above. Heterotrophy may become even smaller when assum-
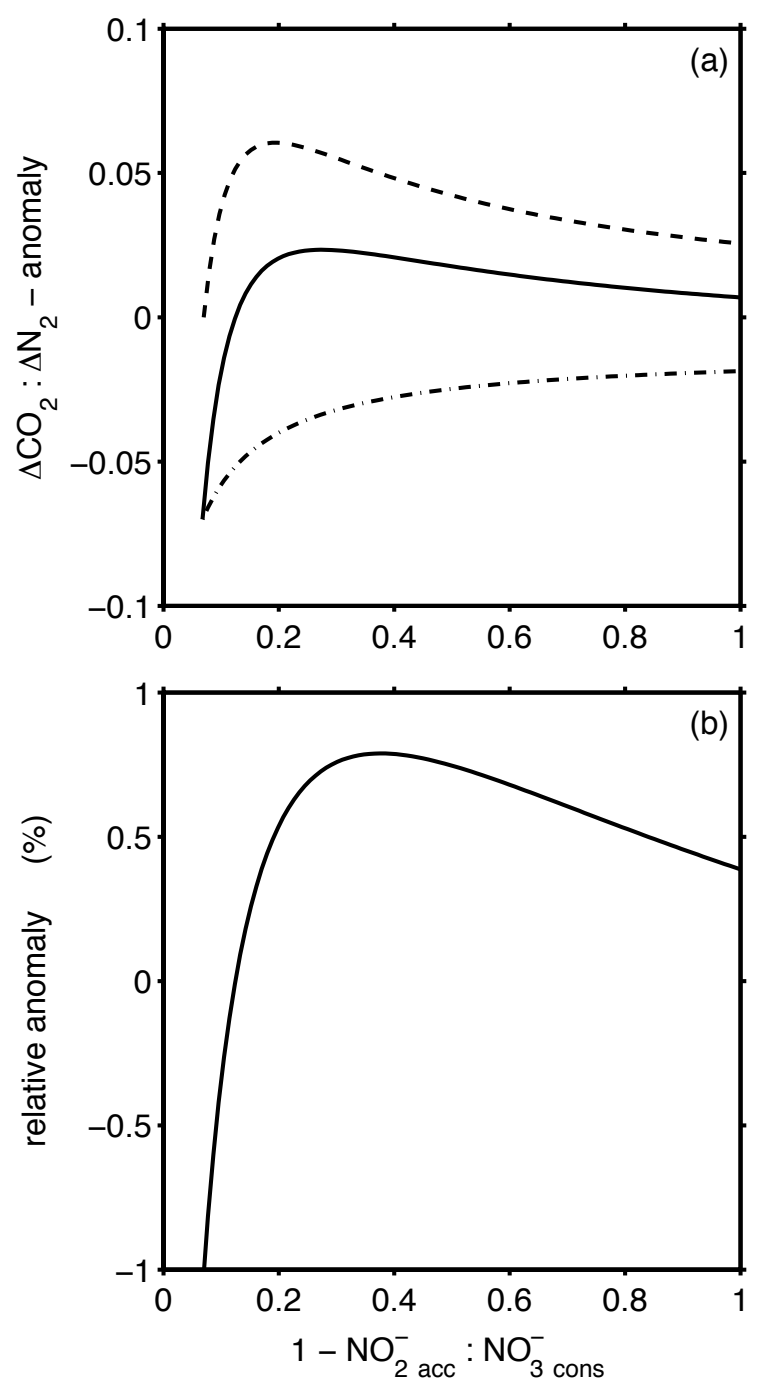

Fig. 3. Effects of autotrophic $\mathrm{CO}_{2}$ fixation on $\Delta \mathrm{CO}_{2}: \Delta \mathrm{N}_{2}$ ratio (for scenario I). (a) Absolute anomalies (mol:mol). Dash-dotted line shows the direct effect of $\mathrm{CO}_{2}$ fixation on $\Delta \mathrm{CO}_{2}: \Delta \mathrm{N}_{2}$ as difference between $\Delta \mathrm{CO}_{2}: \Delta \mathrm{N}_{2}$ (corrected for $\mathrm{CO}_{2}$-fixation) and $\Delta \mathrm{CO}_{2}: \Delta \mathrm{N}_{2}$ (without this correction). Dashed line shows the indirect effect from $\mathrm{NO}_{3}^{-}$production during anammox on $\Delta \mathrm{CO}_{2}: \Delta \mathrm{N}_{2}$ as difference between $\Delta \mathrm{CO}_{2}: \Delta \mathrm{N}_{2}$ (corrected for $\mathrm{NO}_{3}^{-}$-production) and $\Delta \mathrm{CO}_{2}: \Delta \mathrm{N}_{2}$ (without this correction). This indirect effect acts on values of the $\mathrm{x}$-axes, not the $\Delta \mathrm{CO}_{2}: \Delta \mathrm{N}_{2}$ itself. The solid line gives the combination of both effects. (b) Plot shows the relative anomaly $(\%)$, i.e. the combined anomaly due to $\mathrm{CO}_{2}$ fixation and $\mathrm{NO}_{3}^{-}$-production from (a) devided by the fully corrected $\Delta \mathrm{CO}_{2}: \Delta \mathrm{N}_{2}$ ratio times 100 .

ing $\mathrm{HS}^{-}$to diffuse upward to combine with nitrate (Konovalov et al., 2008) producing $\mathrm{NO}_{2}^{-}$by an autotrophic process. Under such conditions it is possible that all substrates for the anammox reaction are produced autotrophically. Also $\mathrm{HS}^{-}$ may combine with nitrate producing $\mathrm{N}_{2}$ (chemolithotrophic denitrification; Hannig et al., 2007; Brettar and Rheinheimer, 

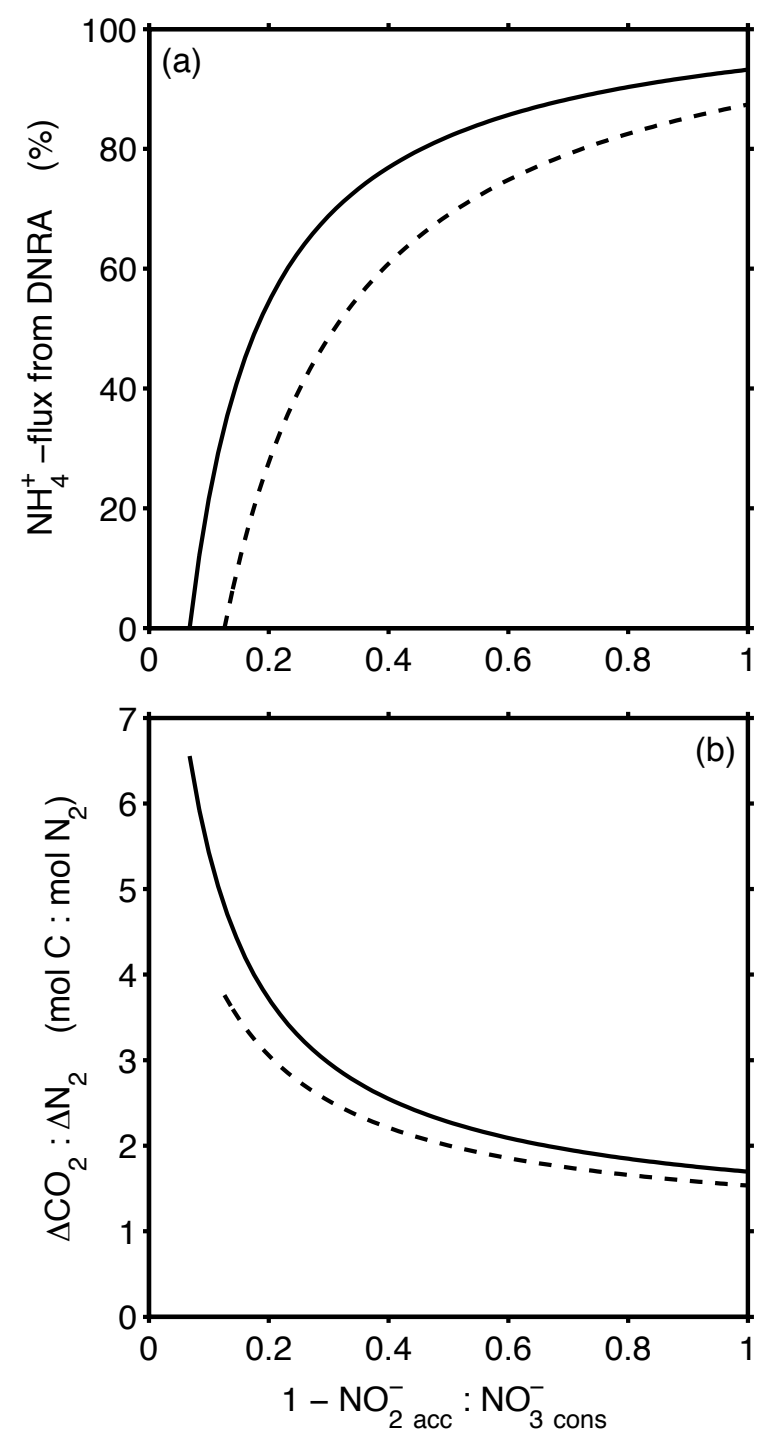

Fig. 4. Scenario II, assuming that suboxic $\mathrm{N}$-conversions are due to a combination of DNRN, DNRA, and anammox. We assume that no $\mathrm{NH}_{4}^{+}$, but variable fractions of $\mathrm{NO}_{2}^{-}$accumulate (see description of x-axes in legend of Fig. 1). Solid lines are for bulk standard organic matter, dashed lines for proteins. (a) Percent fraction of $\mathrm{NH}_{4}^{+}$supply to the anammox reaction from DNRA. (b) $\Delta \mathrm{CO}_{2}: \Delta$ $\mathrm{N}_{2}$ ratio for scenario II.

1991). Hence suboxic $\mathrm{N}_{2}$ production, supplied with substrates from outside, may locally become fully autotrophic. However, diffusion of reduced substrates is accompanied by diffusive $\mathrm{CO}_{2}$-fluxes from the remote heterotrophic decomposition of organic matter by sulphate reduction, which drive the overall $\Delta \mathrm{CO}_{2}: \Delta \mathrm{N}_{2}$ back into the positive range.

While sulphate reduction can supply $\mathrm{NH}_{4}^{+}$to the suboxic layer from below, there is also the possibility of $\mathrm{NH}_{4}^{+}$entering from above. The primary $\mathrm{NH}_{4}^{+}$maximum at the base of the euphotic zone is a characteristic feature of open-ocean $\mathrm{NH}_{4}^{+}$distribution (Brzezinski, 1988). Where surface pro-
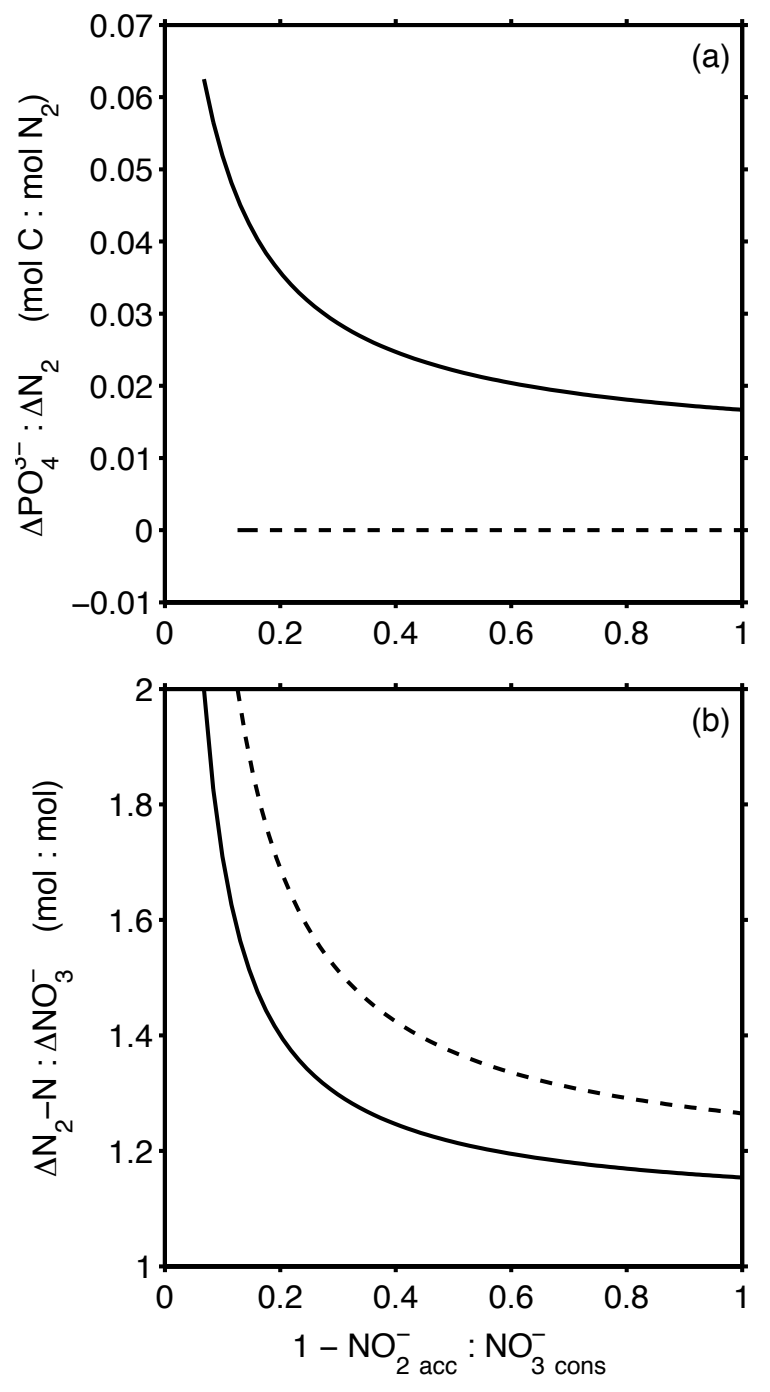

Fig. 5. Scenario I and II. Solid lines are for bulk organic matter composition, dashed lines for proteins. (a) The ratio of phosphate released per $\mathrm{N}_{2}$ formed. (b) The molar ratio of $\mathrm{N}_{2}-\mathrm{N}$ released to nitrate used during $\mathrm{N}$-conversion.

duction and carbon turnover are high like in upwelling regions, $\mathrm{NH}_{4}^{+}$concentrations as high as $0.5 \mu \mathrm{mol} / \mathrm{L}$ have been observed in this layer (Gibb et al., 1999; Molina et al., 2005; Molina and Farías, 2009). It is under such conditions that also the lower slope of the primary $\mathrm{NH}_{4}^{+}$maximum and the oxycline coincide, and diffusive fluxes of $\mathrm{NH}_{4}^{+}$across the upper fringe of the OMZ may occur. Whether this is a significant $\mathrm{NH}_{4}^{+}$source for suboxic anammox may, however, be debated. On thermodynamic grounds (e.g. Brewer and Peltzer, 2009) it can be argued that, assuming similar energy yields for (oxic) nitrification (to $\mathrm{NO}_{2}^{-}$) and (suboxic) anammox, nitrite concentrations larger than its oxygen equivalent (i.e. about $3 / 2 *\left[\mathrm{O}_{2}\right]$ ) are needed for anammox to be more effective in oxidising $\mathrm{NH}_{4}^{+}$than nitrification. However, kinetics will matter as well. Nanomolar half saturation 


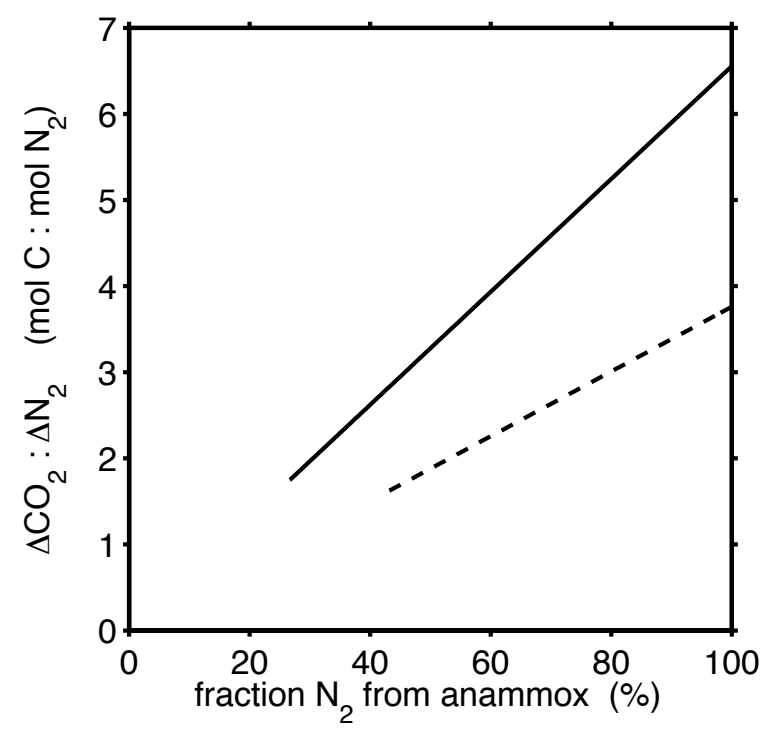

Fig. 6. $\Delta \mathrm{CO}_{2}: \Delta \mathrm{N}_{2}$ vs. percent fraction of $\mathrm{N}_{2}$ produced by the anammox reaction for scenario I (DNRN+denitrification+anammox). Solid line is for bulk organic matter compositions, dashed line for proteins.

constants of aerobic ammonia oxidation and surge-uptake of substrate pulses have recently been observed in nitrifying archaea (Martens-Habbena et al., 2009). Unfortunately, $15 \mathrm{~N}$-isotope experiments of anammox studies have usually applied micro-molar tracer additions, often larger than the ambient substrate concentration, and therefore provide potential rather than in situ substrate uptake rates (Hamersley et al., 2007). It is therefore difficult to compare in situ kinetics of aearobic and anaerobic ammonium oxidation. From the thermodynamic argument given above we conclude that it appears more likely that low-oxygen nitrification stops at the $\mathrm{NO}_{2}^{-}$level, providing $\mathrm{NO}_{2}^{-}$rather than $\mathrm{NH}_{4}^{+}$to anammox (e.g. Schmidt et al., 2002) via diffusion of substrates into suboxic layers. Anyway, the $\mathrm{NH}_{4}^{+}$invading suboxic waters from above is of heterotrophic origin from the oxic remineralisation of organic matter and hence should be accompanied by diffusive fluxes of respiratory $\mathrm{CO}_{2}$, similar as in an anoxic system underlying suboxic zones discussed above. This should drive the $\Delta \mathrm{CO}_{2}: \Delta \mathrm{N}_{2}$ ratio of the upper margin of the OMZ back towards values computed for autochthonous substrate sources of anammox.

\section{Discussion}

Considering autochthonous sources of $\mathrm{NH}_{4}^{+}$and $\mathrm{NO}_{2}^{-}$to anammox and a coupled system with DNRN, denitrification and anammox, we find the somewhat counterintuitive relationship that the higher the contribution of autotrophic anammox to pelagic $\mathrm{N}_{2}$-production, the more heterotrophic the system is (Fig. 6). Hence the feedback switch proposed by
Voss and Montoya (2009) to the effect that expending OMZs (Stramma et al., 2008; Oschlies et al., 2008) will either act as positive or negative feedbacks in the carbon cycle depending on whether anammox or denitrification dominate $\mathrm{N}_{2}$ production in OMZs does not exist. Including additional autochthonous $\mathrm{NH}_{4}^{+}$sources from DNRA does not change the picture significantly. Even when combining DNRA, DNRN, and anammox in scenarios with anammox always contributing 100 percent to $\mathrm{N}_{2}$ production, the coupled system is always heterotrophic. What appears to be variable in both systems is the degree of heterotrophy, however, depending on the efficiency of $\mathrm{N}_{2}$-production.

Allochthonous supply of $\mathrm{NH}_{4}^{+}$(or $\mathrm{NH}_{4}^{+}$and $\mathrm{NO}_{2}^{-}$) may contribute to the substrate needs of anammox, as has been observed in the Black Sea (Murray et al., 2005; Fuchsman et al., 2008; Konovalov et al., 2008). In such a situation, $\Delta \mathrm{CO}_{2}: \Delta \mathrm{N}_{2}$ ratios in the suboxic layer are much lower than with autochthonous substrate supply, and hence the degree of heterotrophy is lower. However, the $\mathrm{NH}_{4}^{+}$diffusing from anoxic waters underlying a suboxic system is from organic matter remineralised via heterotrophic sulphate reduction, which has a concomitant $\mathrm{CO}_{2}$ production. Hence $\mathrm{NH}_{4}^{+}$ fluxes go along with $\mathrm{CO}_{2}$ fluxes. $\mathrm{NH}_{4}^{+}$and total dissolved sulfide $\left(\mathrm{S}_{\mathrm{T}}=\mathrm{H}_{2} \mathrm{~S}+\mathrm{HS}^{-}+\mathrm{S}^{2-}\right)$ as well as $\mathrm{S}_{\mathrm{T}}$ and total dissolved inorganic carbon $\left(\mathrm{C}_{\mathrm{T}}\right)$ co-vary linearly over much of the anoxic water body of the Black Sea (Volkov and Rozanov, 2006). Averaging over anoxic waters from the upper $2000 \mathrm{~m}$ Volkov and Rozanov (2006) find $\mathrm{S}_{\mathrm{T}}-\mathrm{NH}_{4}^{+}$slopes of 4.29 and $\mathrm{C}_{\mathrm{T}}-\mathrm{S}_{\mathrm{T}}$ slopes of 2.01, indicating an average $\mathrm{C}: \mathrm{N}$ ratio of remineralisation of 8.6 which is close to that of bulk standard organic matter. Just below the suboxic layer, however, the $\mathrm{HS}^{-}$ to $\mathrm{NH}_{4}^{+}$slope is less (about 2) which if combined with the average $\mathrm{C}_{\mathrm{T}}-\mathrm{S}_{\mathrm{T}}$ plot yields a $\mathrm{C}: \mathrm{N}$ ratio of only 4.2. There is the possibility that this reduction in the apparent $\mathrm{C}: \mathrm{N}$ remineralisation ratio can be explained as due to nitrogen-rich material (proteins) preferentially remineralised in the upper part of the anoxic layer. This has been suggested for other low oxygen waters by van Mooy et al. (2002). Alternatively, this difference in the apparent $\mathrm{C}: \mathrm{N}$ ratio can be taken as another indication of the quantitative importance of anammox in close-by suboxic waters, providing a significant sink for $\mathrm{NH}_{4}^{+}$but not for $\mathrm{CO}_{2}$, as evident from the observed low $\mathrm{CO}_{2}: \mathrm{NH}_{4}^{+}$efficiency of the anammox reaction (Strous et al., 1998; Tijhuis et al., 1993). Though details will depend on the respective $\mathrm{NH}_{4}^{+}$supplies by diffusion or autochthonous sources, respectively, the overall $\Delta \mathrm{CO}_{2}: \Delta \mathrm{N}_{2}$ ratio should be larger than in the most extreme case computed above $\left(\Delta \mathrm{CO}_{2}: \Delta \mathrm{N}_{2}=+0.38\right)$ and approach the autochthonous ratio $\left(\Delta \mathrm{CO}_{2}: \Delta \mathrm{N}_{2}=+1.75\right)$.

Summarizing the above discussion, we find no simple relationship between the contribution of anammox to total $\mathrm{N}_{2}$-production and the degree of heterotrophy. In particular, where autotrophic anammox contributes 100 percent to suboxic $\mathrm{N}_{2}$-production, we find $\Delta \mathrm{CO}_{2}: \Delta \mathrm{N}_{2}$ yields varying between about +2 and +6 for open ocean OMZs. 
Biogeochemically the system is clearly heterotrophic although autotrophic reactions are a vital element shaping the observed tracer distribution. Low, even negative, values of the $\Delta \mathrm{CO}_{2}: \Delta \mathrm{N}_{2}$ ratio can be computed where substrates are imported from anoxic domains and if associated diffusive $\mathrm{CO}_{2}$ fluxes are ignored.

In Figs. 1-5 we use the property "1 $\mathrm{NO}_{2}^{-}$accumulated $: \mathrm{NO}_{3}^{-}$consumed" as master variable in our discussion of suboxic nitrogen conversions. This property can vary between 0 and 1 , reflecting a fully inefficient system where a large fraction of $\mathrm{NO}_{2}^{-}$accumulates and a fully efficient system with no $\mathrm{NO}_{2}^{-}$accumulation, respectively. In our model computations both numerator $\left(\mathrm{NO}_{2}^{-}\right.$accumulated $)$ and denominator $\left(\mathrm{NO}_{3}^{-}\right.$consumed $)$are well constrained. When applying the results to the real ocean the denominator has to be estimated from observed data and a number of assumptions. One approach to quantify $\mathrm{NO}_{3}^{-}$consumed is the $\mathrm{NO}_{3}^{-}$deficit-approach (Cline and Richards, 1972). In this approach the nitrate deficit is computed as the difference between expected and observed nitrate concentration, where the expected nitrate concentration can for example be computed from observed phosphate concentrations and a $\mathrm{N}: \mathrm{P}$ ratio assumed or derived for the source waters of the OMZ. Including a correction for phosphate release during nitrate based oxidation of organic matter, a general form may be written

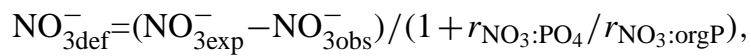

with $r_{\mathrm{NO}_{3} \text { :orgP }}$ as the ratio of nitrate consumed per Pequivalent of organic matter remineralised and $r_{\mathrm{NO}_{3}: \mathrm{PO}_{4}}$ as the nitrate to phosphate ratio in the source water. The expected nitrate concentration can for example be computed from

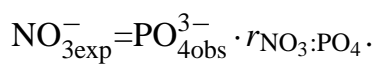

We use the Pacific subset of the GLODAP dataset (Key et al., 2004) to describe examplarily the vertical distribution of the $\mathrm{N}$-conversion efficiency in low oxygen waters (Fig. 7). Values of " $1-\mathrm{NO}_{2}^{-}$accumulated $: \mathrm{NO}_{3}^{-}$consumed" observed in the Pacific OMZs $\left(\left[\mathrm{O}_{2}\right]<5 \mathrm{mmol} \mathrm{m}^{-3}\right)$ range between 0.4 and 1 , and 0.1 and 1, depending on the choosen form of Eq. (2) (see legend of Fig. 7 for details). In principle, the full range of $\mathrm{N}$-conversion efficiencies theoretically possible is expressed in these real ocean data and we conclude that the full range of $\Delta \mathrm{CO}_{2}: \Delta \mathrm{N}_{2}$ may be found in the ocean as well.

Would the absence or presence of anoxic zones, or their extent, in the ocean have any collateral effects on the marine carbon balance at all? So far we emphazised that autotrophic anammox in OMZs depends on substrates $\left(\mathrm{NH}_{4}^{+}\right)$provided by heterotrophic processes either locally, or from neighbouring water layers. Heterotrophic and autotrophic processes are similarly coupled also everywhere else in the aphotic oxic watersphere. Oxic remineralisation of organic matter there releases $\mathrm{CO}_{2}, \mathrm{PO}_{4}^{3-}$ and $\mathrm{NH}_{4}^{+}$

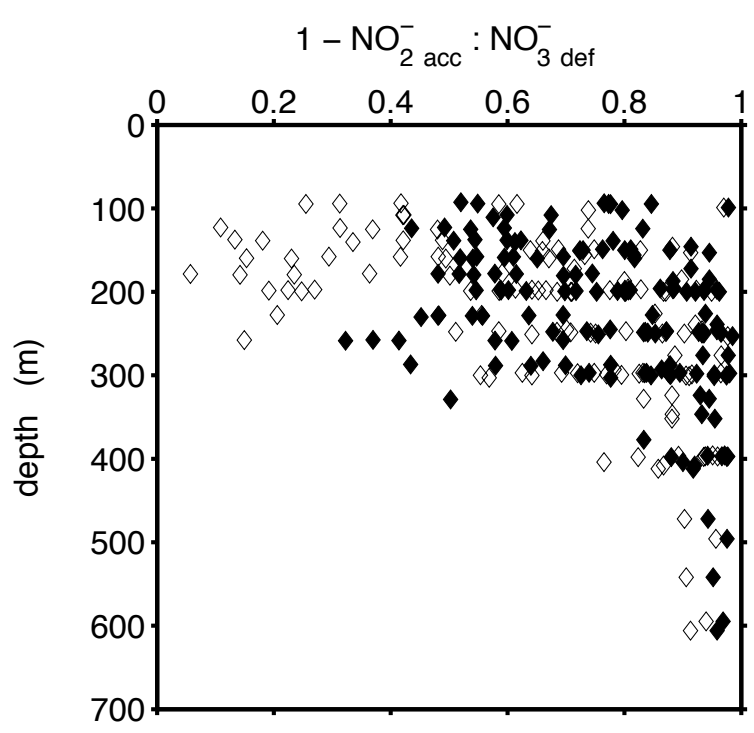

Fig. 7. Vertical distribution of the N-conversion efficiency (1 $\mathrm{NO}_{2}^{-}$acc $: \mathrm{NO}_{3}^{-}$exp) in data from Pazific low oxygen waters (subset of GLODAP database, Key et al. (2004); $\left[\mathrm{O}_{2}\right]<5 \mathrm{mmol} \mathrm{m}^{-3}$, $\mathrm{Z}>80 \mathrm{~m}$ ). Results for two estimates of $\mathrm{NO}_{3}^{-} \exp$ are shown. Solid symbols: $\mathrm{NO}_{3}^{-}$exp is computed according to Eq. (2) with $r_{\mathrm{NO}_{3}: \mathrm{PO}_{4}}=16$. Open symbols: $\mathrm{NO}_{3}^{-}$exp is computed as in Devol et al. (2006), i.e. $\mathrm{NO}_{3}^{-}$exp $=14.89 \cdot\left(\mathrm{PO}_{4}^{3-}\right.$ obs -0.28$)$. The term " $1 /(1+$

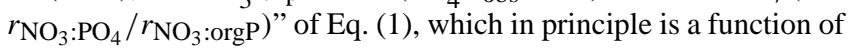
the $\mathrm{N}$-conversion efficiency and the organic matter composition, is approximated with a constant value $(0.87=1 /(1+16 / 104))$, which is based on the stoichiometry of Reaction (R1).

to ambient waters. $\mathrm{NH}_{4}^{+}$does not accumulate (Brezezinski, 1988) under oxic conditions but is subsequently oxidized autotrophically to nitrite and nitrate by nitrifying bacteria and archaea (Ward, 2008). The carbon fixation efficiency of nitrifyers is low $\left(\Delta \mathrm{CO}_{2}: \Delta \mathrm{NH}_{4}^{+}=0.03 \mathrm{~mol}: \mathrm{mol}\right.$, $\left.\Delta \mathrm{CO}_{2}: \Delta \mathrm{NO}_{2}^{-}=0.01 \mathrm{~mol}: \mathrm{mol}\right)$ and generation times are in the order of 10 to $20 \mathrm{~h}$ (Ward, 2008). For mean C:N:P ratios of organic matter of 106:16:1 the gross carbon yield of the heterotrophic oxidation of organic matter is 106:1, the net yield, including the effect of autotrophic nitrification is 105:1 (106-16 - efficiency), i.e. at most 1 percent less. In fact, one may conclude in analogy to the fate of most phototrophic production in the surface ocean that most of the chemoautotrophic $\mathrm{CO}_{2}$-fixation in the interior of the ocean will be recycled and respired in situ as well, bringing the overall $\Delta \mathrm{CO}_{2}: \Delta \mathrm{P}$ ratio back close to $106: 1$. Biogeochemically, also the oxic aphotic ocean is clearly heterotrophic although autotrophic reactions are a vital element shaping the observed tracer distribution, i.e. the accumulation of $\mathrm{NO}_{3}^{-}$instead of $\mathrm{NH}_{4}^{+}$. Making up a similar P-normalised budget for suboxic waters, we find that for both DNRN+denitrification+anammox and for DNRN+DNRA+anammox scenarios the net $\mathrm{CO}_{2}: \mathrm{P}$ is constant $(\approx 105: 1)$ and basically indistinguishable from that of 
oxic conditions. Hence there is no significant difference between suboxic and oxic systems of the aphotic zone of the ocean concerning their trophic state.

Acknowledgements. This work was funded by the CAU Excellence Cluster "The Future Ocean" and the BMBF-International Buero German-Turkish bilateral project "IntenC". This study profited from discussions within the Seeburg Team and with Andreas Oschlies and from suggestions made by three anonymous reviewers.

Edited by: C. P. Slomp

\section{References}

Altabet, M. A., Francois, R., Murray, D. W., and Prell, W. L.: Climate-related variations in denitrification in the Arabian Sea from sediment ${ }^{15} \mathrm{~N} /{ }^{14} \mathrm{~N}$ ratios, Nature, 373, 506-509, 1995.

Anderson, L. A.: On the hydrogen and oxygen content of marine phytoplankton, Deep-Sea Res. I, 42, 1675-1680, 1995.

Brettar, I. and Rheinheimer, G.: Denitrification in the Central Baltic: evidence for $\mathrm{H}_{2} \mathrm{~S}$-oxidation as motor of denitrification at the oxic-anoxic interface, Mar. Ecol. Prog. Ser., 77, 157-169, 1991.

Brewer, P. G. and Peltzer, E. T.: Limits to marine life, Science, 324, 347-348, 2009.

Broda, E.: Two kinds of lithotrophs missing in nature, Z. Allg. Mikrobiol., 17, 491-493, 1977.

Brzezinski, M. A.: Vertical distribution of ammonium in stratified oligotrophic waters, Limnol. Oceanogr., 33, 1176-1182, 1988.

Canfield, D. E.: Models of oxic respiration, denitrification and sulfate reduction in zones of coastal upwelling, Geochim. Cosmochim. Acta, 70, 5753-5765, 2006.

Cline, J. D. and Richards, F. A.: Oxygen deficient conditions and nitrate reduction in the eastern tropical North Pacific Ocean, Limnol. Oceanogr., 17, 885-900, 1972.

Codispoti, L. A.: Is the ocean losing nitrate?, Nature, 376, 724, 1995.

Codispoti, L. A. and Christensen, J. P.: Nitrification, denitrification and nitrous oxide cycling in the eastern tropical South Pacific ocean, Mar. Chem., 16, 277-300, 1985.

Codispoti, L. A., Friederich, G. E., Murray, J. W., and Sakamoto, C. M.: Chemical variability in the Black Sea: implications of continuous vertical profiles that penetrated the oxic/anoxic interface, Deep-Sea Res., 38(S2), S691-S710, 1991.

Devol, A. H.: Denitrification including anammox, in: Nitrogen in the Marine Environment, 2nd Edition, edited by: Capone, D., Bronk, D., Mulholland, M., and Carpenter, E., Elsevier, Amsterdam, 263-301, 2008.

Devol, A. H., Uhlenhopp, A. G., Naqvi, S. W. A., et al.: Denitrification rates and excess nitrogen gas concentrations in the Arabian Sea oxygen deficient zone, Deep-Sea Res., 53, 1533-1547, 2006.

Fuchsman, C. A., Murray, J. W., and Konovalov, S. K.: Concentration and natural stable isotope profiles of nitrogen species in the Black Sea, Mar. Chem., 111, 90-105, 2008.

Ganeshram, R. S., Pedersen, T. F., Calvert, S. E., and Murray, J. W.: Large changes in oceanic nutrient inventories from glacial to interglacial periods, Nature, 376, 755-757, 1995.

Gibb, S. W., Mantoura, R. F. C., Liss, P. S., and Barlow, R. G.: Distributions and biogeochemistries of methylamines and am- monium in the Arabian Sea, Deep-Sea Res. II, 46, 593-615, 1999.

Hamersley, M. R., Lavik, G., Woebken, D., et al.: Anaerobic ammonium oxidation in the Peruvian oxygen minimum zone, Limnol. Oceanogr., 52, 923-933, 2007.

Hanning, M., Lavik, G., Kuypers, M. M. M., et al.: Shift from denitrification to anammox after inflow events in the central Baltic Sea, Limnol. Oceanogr., 52, 1336-1345, 2007.

Hofmann, M. and Schellnhuber, H.-J.: Oceanic acidification affects marine carbon pump and triggers extended marine oxygen holes, P. Natl. Acad. Sci., 106, 3017-3022, doi:10.1073/pnas.0813384106, 2009.

Hulth, S., Aller, R. C., Canfield, D. E., et al.: Nitrogen removal in marine environments: recent findings and future research challenges, Mar. Chem., 94, 125-145, 2005.

Jin, X. and Gruber, N.: Offsetting the radiative benefit of ocean iron fertilization by enhancing $\mathrm{N}_{2} \mathrm{O}$ emissions, Geophys. Res. Lett., 30, 2249, doi:10.1029/2003GL018458, 2003.

Kartal, B., Kuypers, M. M. M., Lavik, G., et al.: Anammox bacteria disguised as denitrifiers: nitrate reduction to dinitrogen gas via nitrite and ammonium, Environ. Microbiol., 9, 635-642, 2007.

Key, R. M., Kozyr, A., Sabine, C. L., Lee, K., Wanninkhof, R., Bullister, J. L., Feely, R. A., Millero, F. J., Mordy, C., and Peng, T.-H.: A global ocean carbon climatology: results from Global Data Analysis Project (GLODAP), Global Biogeochem. Cycles, 18, GB4031, doi:10:1029/2004GB002247, 2004.

Konovalov, S. K., Fuchsman, C. A., Belokopitov, V., and Murray, J. W.: Modelling the distribution of nitrogen species and isotopes in the water column of the Black Sea, Mar. Chem., 111, 106-124, 2008.

Kuenen, J. G.: Anammox bacteria: from discovery to application, Nature Reviews Microbiol., 6, 320-326, 2008.

Kuypers, M. M. M., Sllekers, A. O., Lavik, G., et al.: Anaerobic ammonium oxidation by anammox bacteria in the Black Sea, Nature, 422, 608-611, 2003.

Kuypers, M. M. M., Lavik, G., Woebken, D., et al.: Massive nitrogen loss from the Benguela upwelling system through anaerobic ammonium oxidation, P. Natl. Acad. Sci. USA, 102, 6478-6483, 2005.

Lam, P., Lavik, G., Jensen, M. M., et al.: Revising the nitrogen cycle of the Peruvian oxygen minimum zone, P. Natl. Acad. Sci. USA, 106, 4752-4757, 2009.

Laws, E. A.: Photosynthetic quotients in the open ocean, Deep-Sea Res., 38, 143-167, 1991.

Matear, R. J. and Hirst, A. C.: Long term changes in the dissolved oxygen concentrations in the ocean caused by protracted global warming, Global Biogeochem. Cycles, 17, 1125, doi:10.1029/2002GB001997, 2003.

Martens-Habbena, W., Berube, P. M., Urakawa, H., et al.: Ammonia oxidation kinetics determine niche separation of nitrifying archaea and bacteria, Nature, 461, 976-979, doi:10.1038/nature08465, 2009.

Molina, V. and Farías, L.: Aerobic ammonium oxidation in the oxycline and oxygen minimum zone of the eastern tropical South Pacific off northern Chile ( $\left.20^{\circ} \mathrm{S}\right)$, Deep-Sea Res. II, 56, 10321041, 2009.

Molina, V., Farías, L., Eissler, Y., et al.: Ammonium cycling under a strong oxygen gradient associated with the oxygen minimum zone off northern Chile ( $\left.23^{\circ} \mathrm{S}\right)$, Mar. Ecol. Prog. Ser., 288, 35- 
43, 2005.

Mulder, A., van de Graaf, A. A., Robertson, L. A., and Kuenen, J. G.: Anaerobic ammonium oxidation discovered in a denitrifying fluidized bed reactor, FEMS Microbiol. Ecol., 16, 177-183, 1995.

Murray, J. W., Fuchsman, C., Kirkpatrick, J., Paul, B., and Konovalov, S. K.: Species and $\delta^{15} \mathrm{~N}$ signatures of nitrogen transformations in the suboxic zone of the Black Sea, Oceanography, 18, 36-47, 2005.

Oschlies, A., Schulz, K. G., Riebesell, U., and Schmittner, A.: Simulated 21st century's increase in oceanic suboxia by $\mathrm{CO}_{2}-$ enhanced biotic carbon export, Global Biogeochem. Cycles, 22, GB4008, doi:10.1029/2007GB003147, 2008.

Paulmier, A., Kriest, I., and Oschlies, A.: Stoichiometries of remineralisation and denitrification in global biogeochemical ocean models, Biogeosciences, 6, 923-935, doi:10.5194/bg-6923-2009, 2009.

Redfield, A. C., Ketchum, B. H., and Richards, F. A.: The influence of organisms on the composition of seawater, in: The sea, Vol 2, edited by: Hill, M. N., John Wiley and Sons, New York, 26-77, 1963.

Richards, F. A.: Anoxic basins and fjords, in: Chemical Oceanography, edited by: Riley, J. P. and Skirrow, G., Academic Press, London, 611-643, 1965.

Schmidt, I., Sliekers, O., Schmid, M., et al.: Aerobic and anaerobic ammonia oxidizing bacteria - competitors or natural partners?, FEMS Microbiol. Ecol., 39, 175-181, 2002.

Sen Gupta, R. and Koroleff, F.: A quantitative study of nutrient fractions and a stoichiometric model of the Baltic, Estuar. Coast. Mar. Sci., 1, 335-360, 1973.

Sen Gupta, R. and Naqvi, S. W. A.: Chemical oceanography of the Indian Ocean, north of the aquator, Deep-Sea Res., 31, 671-706, 1984.

Stramma, L., Johnson, G. C., Sprintall, J., and Mohrholz, V.: Expanding oxygen-minimum zones in the tropical oceans, Science, 320, 655-658, 2008

Strous, M., Heijnen, J. J., Kuenen, J. G., and Jetten, M. S. M.: The sequencing batch reactor as a powerful tool to study very slowly growing micro-organisms, Appl. Microbiol. Biotechnol., 50, 589-596, 1998.

Stumm, W. and Morgan, J. J.: Aquatic chemistry - chemical equilibria and rates in natural waters, John Wiley \& Sons, Inc., New York, 1022 pp., 1996.
Thamdrup, B. and Dalsgaard, T.: Production of $\mathrm{N}_{2}$ through anaerobic ammonium oxidation coupled to nitrate reduction in marine sediments, Appl. Environ. Microbiol., 68, 1312-1318, 2002.

Thamdrup, B., Dalsgaard, T., Jensen, M. M., et al.: Anaerobic ammonium oxidation in the oxygen-deficient waters off northern Chile, Limnol. Oceanogr., 51, 2145-2156, 2006.

Thomas, W. H.: On denitrification in the northeastern tropical Pacific Ocean, Deep-Sea Res., 13, 1109-1114, 1966.

Tijhuis, L., Van Loosdrecht, M. C. M., and Heijnen, J. J.: A thermodynamically based correlation for maintenance Gibbs energy requirements in aerobic and anaerobic chemotrophic growth, Biotechnol. Bioeng., 42, 509-519, 1993.

van de Graaf, A. A., de Bruijn, P., Robertson, L., Jetten, M. S. M., and Kuenen, J. G.: Autotrophic growth of anaerobic ammoniumoxidizing micro-organisms in a fluidized bed reactor, Microbiol., 142, 2187-2196, 1996.

Van Mooy, B. A. S., Keil, R. G., and Devol, A. H.: Impact of suboxia on sinking particulate organic carbon: enhanced carbon flux and preferential degradation of amino acids via denitrification, Geochim. Cosmochim. Acta, 66, 457-465, 2002.

Volkov, I. I. and Rozanov, A. G.: Fundamentals of biohydrochemistry of anoxic basins, Oceanology, 46, 803-816, 2006.

Voss, M. and Montoya, J. P.: Oceans apart, Nature, 461, 49-50, 2009.

Ward, B. B.: Nitrification in marine systems, in: Nitrogen in the Marine Environment, 2nd Edition, edited by: Capone, D., Bronk, D., Mulholland, M., and Carpenter, E., Elsevier, Amsterdam, 2008.

Ward, B. B., Capone, D. G., and Zehr, J. P.: What's new in the nitrogen cycle?, Oceanography, 20, 101-109, 2007.

Ward, B. B., Devol, A. H., Rich, J. J., Chang, B. X., Bulow, S. E., Naik, H., Pratihary, A., and Jayakumar, A.: Denitrification as the dominant nitrogen loss process in the Arabian Sea, Nature, 461, 78-81, 2009.

Yoshinari, T. and Knowles, R.: Acetylene inhibition of nitrous oxide reduction by denitrifying bacteria, Biochem. Biophys. Res. Comm., 69, 705-710, 1976.

Zafiriou, O. C., Ball, L. A., and Hanley, Q.: Trace nitrite in oxic waters, Deep-Sea Res., 39, 1329-1347, 1992.

Zumft, W. G.: Cell biology and molecular basis of denitrification, Microbiol. Mol. Biol. Rev., 61, 533-616, 1997. 